\title{
EFEKTIVITAS EDUKASI GIZI MENGGUNAKAN MEDIA KOMIK TERHADAP PENGETAHUAN DAN SIKAP TENTANG GIZI SEIMBANG PADA SISWA SEKOLAH DASAR
}

\author{
EFECTIVITY NUTRITION EDUCATION USING MEDIA OF \\ COMIC-BOOK TO ELEMENTARY SCHOOL STUDENTS' KNOWLEDGE AND ATTITUDE OF BALANCED NUTRIENT
}

\author{
Enggar Redyastuti, Wiwik Wijaningsih, M. Jaelani, Yuniarti, Meirina Dwi Larasati
}

\begin{abstract}
Background : Some issue found during preliminary survey and have not revealed the good dietary habit with balanced nutrient; for example: did not bring lunch and drink from home, buy unhealthy snack outside the school, and low knowledge about the importance of high protein side-dish, vegetables, and fruits. Nutrition education for elementary school students can support them to have good dietary habit. Using media can help us to give information.
\end{abstract}

Objective : To know the influence of giving an education of balanced nutrient using media of comic-book with the content: knowledge and attitude of balanced nutrient to elementary school students.

Methods : This research is classified to community nutrition research. The type of research is quasi experimental design and the plan is design with the pretest - posttest control group design. Total sample is 72 students, divided into treated-group and control-group. Collected data are identity, pretest and posttest result of knowledge-andattitude. The test method that be used are Independent $t$-test and Mann Whitney.

Results : Average score of knowledge in treated-group increased 6,36 points and in control-group 3,79 points. Average score of attitude in treated-group increased 0,98 points and in control-group 1,82 points.

Conclusion : There were significantimpact of giving nutrition education using media of comic-book towardsbalanced nutrition knowledge on elementary school students $(p=0,017)$, while on the attitude the improvement is not significant, $(p=0,549)$.

Keywords : knowledge, attitude, nutrition-education, comic-book

\section{ABSTRAK}

Latar Belakang : Beberapa masalah yang ditemui pada saat survey dan belum mencerminkan pola makan yang bergizi seimbang antara lain belum ada kesadaran untuk membawa bekal makan atau minum, jajan di luar sekolah sesukanya, dan masih rendahnya pengetahuan tentang pentingnya konsumsi lauk berprotein tinggi, sayur, dan buah. Pendidikan gizi pada anak sekolah dapat membantu dalam mengarakhan membiasakan dan cara makan yang baik. Penggunaan media dapat membantu dalam menyampaikan informasi.

Tujuan : Mengetahui pengaruh pemberian edukasi gizi menggunakan media komik pengetahuan dan sikap tentang gizi seimbang pada siswa sekolah dasar.

Metode : Jenispenelitian yang digunakanadalahquasi experimental design dengan rancangan pretest - posttest control group design. Jumlah sampel sebanyak 72 siswa yang dibagi menjadi kelompok perlakuan dan kelompok kontrol.Uji yang digunakanyaitulndependent t-test danMann whitney.

Hasil : Rata-rata skor pengetahuan pada kelompok perlakuan meningkat sebesar 6,36 poin, sedangkan pada kelompok control hanya sebesar 3,79 poin. Rata-rata skorsikap pada kelompok perlakuan meningkat sebesar 0,98 poin dan pada kelompok control menurun 1,82 poin. 
Kesimpulan : Ada pengaruh yang signifikan pemberian edukasi gizi menggunakan media komik terhadap pengetahuan tentang gizi seimbang pada siswa sekolah dasar $(p=0,017)$, sedangkan pada sikap kenaikannya tidak signifikan $(p=0,549)$.

Kata kunci : pengetahuan, sikap, edukasigizi, media komik

\section{PENDAHULUAN}

Pengetahuan merupakan hasil pengindraan seseorang atau hasil "tahu" dari seseorang terhadap objek melalui indra yang dimilikinya (mata, hidung, telinga, dan sebagainya). Sebagian besar pengetahuan seseorang diperoleh melalui indera pendengaran (telinga) dan indera penglihatan (mata). Sikap merupakan respon tertutup terhadap suatu stimulus atau objek tertentu yang melibatkan pendapat dan emosi (1). Penelitian menunjukkan bahwa pengetahuan gizi anak SD sebelum pemberian edukasi gizi sebesar $66,46 \%$ dan meningkat menjadi $71,61 \%$ setelah adanya edukasi gizi (2). Hal ini menunjukkan bahwa edukasi gizi masih sangat diperlukan untuk memberikan pengetahuan gizi sejak dini khususnya pada anak SD.

Sikap siswa sebelum diintervensi tentang konsumsi jajanan berada pada kategori cukup (80\%) dan kurang (20\%). Sikap siswa $100 \%$ menunjukkan baik setelah adanya intervensi, dengan demikian berarti pemberian edukasi gizi memiliki peran dalam menentukan sikap anak (3).

Pendidikan gizi yang diberikan kepada anak di sekolah dapat mengarahkan pada pembiasaan dan cara makan yang baik (4). Dalam pendidikan kesehatan perlu adanya perencanaan untuk menentukan metode yang akan digunakan sesuai dengan tujuan yang ingin dicapai. Bila tujuannya untuk memberikan pengertian dapat menggunakan tertulis atau lisan, sedangkan bila tujuannya untuk mengembangkan sikap positif bisa menggunakan bentuk gambar, film, ataupun foto. Begitu pula dengan pemilihan alat peraga atau media yang digunakan untuk membantu menyampaikan informasi agar mudah diterima (5).

Penggunaan cerita bergambar lebih efektif untuk meningkatkan hasil belajar keterampilan berbahasa (menyimak dan membaca). Hasil penelitiannya menyatakan bahwa terdapat perbedaan hasil keterampilan berbahasa (menyimak dan membaca) antara peserta didik yang menggunakan media cerita bergambar dan peserta didik yang tanpa menggunakan cerita bergambar (6). Media komik dapat meningkatkan pengetahuan remaja tentang gaya hidup $3 \mathrm{x}$ dibanding jika menggunakanmedia leaflet, sedangkan pada sikap dengan media komik meningkat $4 \mathrm{x}$ dibanding media leaflet. ${ }^{7}$ Penelitian lain juga mengungkapkan bahwa sebanyak $83 \%$ anak lebih memilih komik dibanding buku (7).

\section{METODE}

Penelitian ini merupakan penelitian quasi experimental design dengan rancangan penelitian pretest - posttest control group design. Penelitian dilakukan pada bulan April-Mei 2017 pada 36 siswa kelas V di SDN Bugangan 3 Kota Semarang sebagai kelompok perlakuan dan 36 siswa di SDN Rejosari 01 Kota Semarang sebagai kelompok kontrol.Sampel diambil kelas $\mathrm{V}$ karena pada masa ini anak masuk dalam kelas tinggi sekolah dasar dan telah mencapai objektivitas tertinggi. Taraf berpikirnya sudah termasuk daam berpikir kokretoperasional atau anak sudah dapat mengenal sesuatu berdasarkan gambaran nyata atauu kenyataan yang dibuat dalam gambar (8).

Data yang dikumpulkan yaitu data primer dan data sekunder. Data primer yang dikumpulkan yaitu:

1. Identitas sampel yang diperoleh dari formulir identitas sampel

2. Skor pengetahuan yang diperoleh dari kuesioner pengetahuan bila benar diberi skor 1 dan bila salah diberi skor 0 . Pengetahuan dikategorikan sebagai < $80 \%$ (kurang) dan $\geq 80 \%$ (baik) yang dihitung dari (total jawaban benar/20) x 100\%.

3. Skor sikap yang diperoleh dari kuesioner sikap dengan skala jawaban sangat setuju, setuju, tidak setuju, dan sangat tidak setuju. Sikap dikategorikan sebagai $<80 \%$ (tidak mendukung) dan $\geq 80 \%$ (mendukung). Skor sikap diperoeh dari perhitungan (skor jawaban benar / 80) x $100 \%$.

Data sekunder yang dikumpulkan yaitu mengenai gambaran umum sekolah yang diperoleh dari catatan dan pelaporan hasil observasi dan wawancara kepada kepala sekolah.

Penelitian melalui dua tahapan yaitu tahap persiapan dan tahap penelitian.Tahap persiapannya yaitu perijinan, survey pendahuluan, pembuatan kuesioner dan komik, uji coba kuesioner dan komik, revisi kuesioner dan komik, produksi komik.Tahapan penelitian yang dilakukan yaitu sampel yang telah ditentukan kemudian dilakukan pretest, kemudian pada kelompok kontrol diberi ceramah saja sedangkan kelompok perlakuan 
diberikan komik.Pemberian intervensi edukasi gizi ini dilakukan sebanyak 2 kali dalam 2 minggu. Setelah dilakukan edukasi gizi selanjutnya yaitu diberikan post test kemudian dilakukan uji beda.

Analisis data univariat digunakan untuk mendiskripsikan variabel yang diteliti yaitu skor pengetahuan dan skor sikap saat sebelum dan sesudah intevensi.Data kategoriknya disajikan dalam tabel distribusi proporsi, sedangkan data numeriknya disajikan daengan nilai rata-rata, minimal, maksimal, dan standar deviasi.

Analisis bivariat digunakan untuk melihat pengaruh edukasi gizi terhadap pengetahuan dan sikap.Perbedaan selisih pengetahuan dan sikap saat sebelum dan sesudah intervensi pada kelompok perlakuan dan kontrol menggunakan uji Independent T-Test jika data berdistribusi normal dan Uji Mann Whitney jika data tidak berdistribusi normal. Ha diterima bila $p<0,05$.

\section{HASIL DAN PEMBAHASAN}

\section{Karakteristik Sampel}

Jumlah sampel yang digunakan yaitu 36 sampel sebagai kelompok perlakuan dan 36 sampel sebagai kelompok kontrol. Akan tetapi saat proses penelitian terdapat 3 sampel pada kelompok perlakuam dan 3 sampel kelompok kontrol yang drop out dikarenakan ijin tidak masuk sekolah sehingga jumlah sampel yang digunakan yaitu sebanyak 33 siswa pada kelompok perlakuan dan 33 siswa pada kelompok kontrol.Distribusi frekuensi sampel berdasarkan jenis kelamin disajikan pada tabel 1.

Tabel 1. Distribusi frekuensi sampel berdasarkan jenis kelamin

\begin{tabular}{ccccc}
\hline \multirow{2}{*}{ Jenis Kelamin } & \multicolumn{2}{c}{ Kelompok perlakuan } & \multicolumn{2}{c}{ Kelompok Kontrol } \\
\cline { 2 - 5 } & $\mathbf{N}$ & $\mathbf{\%}$ & $\mathbf{N}$ & $\mathbf{\%}$ \\
\hline Laki-laki & 16 & 48,5 & 17 & 51,5 \\
Perempuan & 17 & 51,5 & 16 & 48,5 \\
\hline Total & $\mathbf{3 3}$ & $\mathbf{1 0 0}$ & $\mathbf{3 3}$ & $\mathbf{1 0 0}$ \\
\hline
\end{tabular}

Distribusi frekuensi skor pengetahuan pada kelompok perlakuan dan kontrol disajikan dalam tabel 2, sedangkan nilai rata-rata, standar deviasi, minimal dan maksimal tersaji pada tabel 3.
Tabel 2. Distribusi Frekuensi Skor Pengetahuan

\begin{tabular}{|c|c|c|c|c|}
\hline \multirow{3}{*}{$\begin{array}{c}\text { Kategori } \\
\text { Pengetahuan }\end{array}$} & \multicolumn{4}{|c|}{ Kelompok } \\
\hline & \multicolumn{2}{|c|}{ Perlakuan (n=33) } & \multicolumn{2}{|c|}{ Kontrol (ni33) } \\
\hline & $N$ & $x$ & $N$ & $\%$ \\
\hline \multicolumn{5}{|l|}{ Sebelum } \\
\hline$<80 \%$ & 9 & 27,3 & 15 & 45,5 \\
\hline$\geq 80 \%$ & 24 & 72.7 & 18 & 54,5 \\
\hline \multicolumn{5}{|l|}{ Sesudah } \\
\hline$<B O \%$ & 1 & 3 & 9 & 27,3 \\
\hline$\geq 80 \%$ & 32 & 97 & 24 & 72,7 \\
\hline
\end{tabular}

Tabel 3. Nilai Statistik Skor Pengetahuan

\begin{tabular}{cccccccc}
\hline \multirow{2}{*}{ Pengetahuan } & \multicolumn{3}{c}{ Perlakuan $(n=33)$} & \multicolumn{3}{c}{ Kontrol $(n=33)$} \\
\cline { 2 - 8 } & MeantSD & Min & Max & MeantSD & Min & Max \\
\hline Sebelum & $82.58 \pm 7,408$ & 70 & 95 & $78,18 \pm 11,847$ & 45 & 95 \\
Sesudah & $88.94 \pm 5,556$ & 75 & 100 & $81,97 \pm 13,047$ & 40 & 100 \\
\hline
\end{tabular}

Penelitian menunjukkan bahwa pada kelompok perlakuan jumlah siswa yang mendapat skor $\geq 80 \%$ meningkat sebanyak 8 siswa dan hanya 6 siswa pada kelompok kontrol. Rata-rata skor pengetahuan meningkat 6,36 poin pada kelompok perlakuan dan 3,79 poin pada kelompok kontrol.

Pengetahuan merupakan hasil penginderaan atau hasil tahu seseorang terhadap objek melalui ondera yang dimiliki (mata, hidung, telinga, dan lain-lain).Sebagian besar pengetahuan seseorang diperoleh melalui pendengaran (telinga) dan penglihatan (mata).Intensitas atau tingkat pengetahuan seseorang juga berbeda-beda. Secara garis besar dibagi menjadi enam, yaitu: tahu, memahami, aplikasi, analisis, sintesis, dan evaluasi (1).

Pengetahuan seseorang dapat dipengaruhi oleh beberapa faktor, diantaranya: pendidikan atau bimbingan yang diberikan, pekerjaan yang dapat memberikan pengalaman, umur dapat menentukan taraf berpikir, minat dapat menjadikan sesorang untuk menekuni suatu hal, pengalaman dapat menimbulkan kesan, kebudayaan lingkungan sekitar, dan informasi yang pernah didapatkan (9).

Distribusi frekuensi skor sikap pada kelompok perlakuan dan kontrol tersaji pada tabel 4. Nilai rata-rata, standar deviasi, minimal, serta maksimal tersaji pada tabel 5 .

Tabel 4. Distribusi Frekuensi Skor Sikap

\begin{tabular}{|c|c|c|c|c|}
\hline \multirow{3}{*}{ Kategori Sikap } & \multicolumn{4}{|c|}{ Kelampok } \\
\hline & \multicolumn{2}{|c|}{ Perlakuan $(n=33)$} & \multicolumn{2}{|c|}{ Kontrol ( $n=33$ ) } \\
\hline & $N$ & $\psi_{0}$ & $N$ & $\%$ \\
\hline \multicolumn{5}{|l|}{ Sebelum } \\
\hline$<80 \%$ & 16 & 48,5 & 16 & 48,5 \\
\hline$\geq 80 \%$ & 17 & 51,5 & 17 & 51,5 \\
\hline \multicolumn{5}{|l|}{ Sesudah } \\
\hline$<80 \%$ & 15 & 45,5 & 18 & 54,5 \\
\hline$\geq 80 \%$ & 18 & 54,5 & 15 & 45,5 \\
\hline
\end{tabular}


Tabel 5. Nilai Statistik Skor Sikap

\begin{tabular}{cccccccc}
\hline \multirow{2}{*}{ Sikap } & \multicolumn{3}{c}{ Perlakuan (n=33) } & \multicolumn{3}{c}{ Kontrol (n=33) } \\
\cline { 2 - 7 } & Meant50 & Min & Max & MeantS0 & Min & Max \\
\hline Sebelum & $79.66+6,062$ & 69 & 94 & $78,75+6,473$ & 63 & 91 \\
Sesudah & $80.64 \pm 9,376$ & 60 & 99 & $76,93 \pm 8,221$ & 59 & 90 \\
\hline
\end{tabular}

Hasil tersebut menunjukkan bahwa pada kelompok perlakuan jumlah siswa yang mendapat skor sikap $\geq 80 \%$ meningkat sebanyak 1 siswa dan terjadi penurunan 2 siswa pada kelompok kontrol. Rata-rata skor sikap meningkat 0,98 poin pada kelompok perlakuan dan turun 1,82 poin pada kelompok kontrol.

Sikap merupakan suatu reaksi atau respon seseorang terhadap suatu stimulus atau objek. Sikap belum merupakan tindakan atau aktivitas, tetapi merupakan predisposisi tindakan atau perilaku (9).

Faktor-faktor yang dapat mempengaruhi sikap adalah pengalaman pribadi, pengaruh dari orang lain, pengaruh kebudayaan, media massa, lembaga pendidikan atau agama, dan faktor emosional yang biasanya hanya bersifat sementara tetapi dapat juga bersifat persisten atau tahan lama (10).

\section{Pengaruh Edukasi Gizi terhadap Pengetahuan tentang Gizi Seimbang pada Siswa Sekolah Dasar saat Pretest dan Posttest antara Kelompok Perlakuan dan Kelompok Kontrol}

Analisa hasil perbedaan skor pengetahuan menggunakan uji Mann Whitney karena berdasarkan uji kenormalan data berdistribusi tidak normal.Perbedaan skor pengetahuan saat pretest dan posttest pada kelompok perlakuan dan kelompok kontrol disajikan pada tabel 6 .

Tabel 6. Perbedaan Skor Pengetahuan saat Pretest dan Posttest

\begin{tabular}{|c|c|c|c|}
\hline \multirow{2}{*}{$\begin{array}{c}\text { Sker } \\
\text { Pengetahuan }\end{array}$} & \multicolumn{2}{|c|}{ Kelompok } & \multirow[b]{2}{*}{$f$} \\
\hline & $\begin{array}{c}\text { Perlakuas } \\
(n-33)\end{array}$ & $\begin{array}{l}\text { Kontrol } \\
(n-33)\end{array}$ & \\
\hline Sebolum & $82,58+7,408$ & $78,18+11,847$ & 0,118 \\
\hline Sesudah. & $88,94 \pm 5,556$ & $81,97 \pm 13,047$ & 0,017 \\
\hline APengetahuan & $6,36 \pm 6,99$ & $3,79 \pm 10,68$ & 0,356 \\
\hline
\end{tabular}

Hasil analisis pada tabel 6 menunjukkan bahwa edukasi gizi menggunakan komik berpengaruh terhadap peningkatan pengetahuan tentang gizi seimbang $(p=0,017)$ tetapi pada kelompok perlakuan dan kontrol tidak ada perbedaan yang bermakna $(p=0,356)$.
Penelitian ini sejalan dengan penelitian yang dilakukan Arimurti (2012) yang dilakukan pada siswa kelas $\mathrm{V}$ bahwa edukasi dengan media komik dapat meningkatkan pengetahuan. Penelitiannya mengemukakan bahwa setelah intervensi menggunakan media komik terjadi peningkatan pengetahuan dengan perbedaan rata-rata skor pengetahuan sebesar 24,7 $\pm 16,6$. Sedangkan penelitiannya pada kelompok kontrol memiliki perbedaan rata-rata skor pengetahuan sebesar 1,5 $\pm 11,5$ (11).

Pengetahuan tentang gizi merupakan hal yang penting bagi anak karena apabila anak tidak memiliki pengetahuan dapat menyebabkan anak tidak memiliki kemampuan untun menerapkan informasi. Anak dengan pengetahuan gizi yang rendah dapat meningkatkan resiko 2,889 kali lebih sering mengkonsumsi jajanan dibandingkan yang memiliki pengetahuan gizi baik (12) .

Komik adalah rangkaian gambar yang berurutan, tersusun dari gambar-gambar tidak bergerak yang memiliki alur $(13,14) .{ }^{3,8}$ Komik merupakan salah satu media visual. Media visual memegang peran yang sangat penting dalam proses belajar. Media visual dapat memperlancar pemahaman, memperkuat ingatan, menumbuhkan minat siswa, dan memberikan hubungan antara isi materi denan dunia nyata (15).

Komik yang digunakan berisi tentang pesan khusus gizi seimbang untuk anak dan remaja usia 619 tahun. Pesan khususnya yaitu berisi tentang membiasakan makan 3 kali sehari; konsumi ikan dan sumber protein lainnya; perbanyak konsumsi sayur dan buah yang cukup; biasakan membawa bekal makanan dan air putih; membatasi konsumsi makanan cepat saji, jajanan, dan makanan manis, asin, berlemak; biasakan sikat gigi; dan hindari rokok (16).

Edukasi gizi yang dilakukan dengan ceramah dan menggunakan media komik dapat membuat siswa lebih aktif dan tertarik, dapat menumbuhkan motivasi belajar siswa, dapat lebih dipahami oleh siswa, metode belajar lebih bervariasi sehingga tidak bosan, siswa dapat melakukan metode belajar sendiri dan tidak semata-mata hanya mendengarkan penuturan kata-kata oleh guru, siswa juga dapat belajar dengan mengamati gambar pada komik (17).

$\mathrm{Hal}$ ini juga terlihat pada penelitian ini bahwa pada kelompok perlakuan saat diberikan komik lebih antusias dan tertarik selama pemberian edukasi gizi. Dengan membaca, anak dapat melihat alur ceritanya sendiri sehingga akan merasa memiliki pengalaman sendiri. Pada kelompok kontrol sulit dikendalikan untuk terus memperhatikan saat pemberian edukasi gizi dengan 
metode ceramah.Siswa menjadi cepat bosan hanya mendengarkan saja karena metode ceramah yang diberikan cenderung bersifat satu arah. Selain itu, jika hanya dengan mendengarkan saja informasi yang didapat akan berkurang jika tidak berkosentrasi sehingga dapat mempengaruhi pengetahuan yang didapat.

Pengaruh Edukasi Gizi terhadap Sikap tentang Gizi Seimbang pada Siswa Sekolah Dasar sebelum dan Sesudah antara Kelompok Perlakuan dan Kelompok Kontrol

Analisa hasil perbedaan skor sikap menggunakan uji Independent T-Test karena berdasarkan uji kenormalan data berdistribusi normal.Perbedaan skor sikap saat pretest dan posttest pada kelompok perlakuan dan kelompok kontrol disajikan pada tabel 7.

Tabel 7. Perbedaan Skor Sikap saat Pretest dan Posttest

\begin{tabular}{lccc}
\hline \multirow{3}{*}{ Skor Sikap } & \multicolumn{2}{c}{ Kelompok } & \\
\cline { 2 - 3 } & $\begin{array}{c}\text { Perlakuan } \\
(n-33)\end{array}$ & $\begin{array}{c}\text { Kontrol } \\
(n-33)\end{array}$ & \\
\cline { 2 - 3 } Sebelum & $79,66 \pm 6,062$ & $78,75 \pm 6,473$ & 0,994 \\
Sesudah & $80,64 \pm 9,376$ & $76,93 \pm 8,221$ & 0,549 \\
\hline \multicolumn{1}{c}{$\Delta$ Sikap } & $0,98 \pm 9,565$ & $-1,82+6,427$ & 0,056 \\
\hline
\end{tabular}

Hasil analisis pada tabel 7 menunjukkan bahwa edukasi gizi menggunakan komik tidak berpengaruh pada sikap tentang gizi seimbang pada anak sekolah dasar $(p=0,549)$. Penelitian ini sejalan dengan penelitian yang dilakukan oleh Nurhasanah.Penelitiannya yang dilakukan pada siswa sekolah dasar kelas 4, 5, dan 6 menunjukkan bahwa tidak ada pengaruh yang signifikan antara pemberian edukasi pendidikan kesehatan terhadap sikap siswa. Hal ini bisa terjadi karena reaksi dari responden masih berkisar pada tahapan stimulus yang masih bersifat tertutup sehingga manifestasinya tidak dapat langsung dilihat (18).

Tidak adanya pengaruh edukasi gizi pada sikap bisa terjadi karena siswa memiliki emosi dan keyakinan terhadap sikap gizi seimbang yang masih berubah-ubah. Hal ini juga bisa dipengaruhi karena informasi tentang gizi belum diterima dengan baik sehingga anak masih bimbang dalam menjawab pertanyaan dalam kuesioner. Paparan informasi dari media atau orang lain yang lebih kuat dan dipercaya juga dapat mempengaruhi sikap anak.

Faktor-faktor yang dapat mempengaruhi pembentukan sikap adalah pengalaman pribadi, kebudayaan, orang lain yang dianggap penting, media massa, institusi atau lembaga pendidikan, lembaga agama, dan faktor emosi dalam individu yang bersangkutan (19).

\section{KESIMPULAN DAN SARAN}

\section{KESIMPULAN}

Rata-rata skor pengetahuan pada kelompok perlakuan meningkat sebesar 6,36 poin dan pada kelompok kontrol hanya meningkat sebesar 3,79 poin. Hasil uji statistik menggunakan uji Mann Whitney menyatakan bahwa ada pengaruh pemberian edukasi gizi menggunakan media komik terhadap pengetahuan siswa sekolah dasar $(p=0,017)$.

Rata-rata skor sikap pada kelompok perlakuan meningkat sebesar 0,98 poin dan pada kelompok kontrol menurun 1,82 poin. Hasil uji statistic menggunan Idependen T-Test menyatakan bahwa tidak ada pengaruh pemberian edukasi gizi menggunakan media komik terhadap sikap siswa sekolah dasar $(p=0,549)$.

\section{SARAN}

Penelitian selanjutnya sebaiknya menambahkan faktor-faktor lain yang dapat meningkatkan sikap tentang gizi seimbang pada anak sekolah seperti umur, pendidikan orangtua, dan lain sebagainya.

\section{DAFTAR PUSTAKA}

1. 2010. Promosi Kesehatan Teori dan Aplikasinya. Jakarta: Rineka Cipta.

2. Nuryanto, dkk. 2014. "Pengaruh Pendidikan Gizi terhadap Pengetahuan dan Sikap tentang Gizi Anak Sekolah Dasar," Jurnal Gizi Indonesia, 3(1)

3. Siagian, Albiner, Jumirah, Fourgelina Tammpubulon. 2010. "Media Visual Poster dan Leaflet Makanan Sehat serta Perilaku Konsumsi Makanan Jajanan Siswa Sekolah Lanjutan Atas di Kabupaten Mandailing Natal," Jurnal Kesehatan Masyarakat Nasional, 4(6)

4. Santoso, Soegeng dan Anne Lies Ranti. 2013. Kesehatan dan Gizi. Jakarta: Rineka Cipta

5. Sulistyoningsih, Hariyani. 2011. Gizi untuk Kesehatan Ibu dan Anak. Yogyakarta: Graha IImu.

6. Faizah, Umi. 2009. “Keefektifan Cerita Bergambar untuk Pendidikan Nilai dan Keterampilan Berbahasa dalam Pembelajaran Bahasa Indonesia," Cakrawala Pendidikan, 28 (3). 
7. Arimurti, Ditta Irma. 2012. “Pengaruh Pemberian Komik Pendidikan Gizi Seimbang terhadap Pengetahuan Gizi Siswa Kelas V SDN Sukasari 4 Kota Tangerang," Skripsi. Depok: Fakultas Kesehatan Masyarakat Prodi Gizi Universitas Indonesia

8. Vitasari, Rizka, Joharman, Kartika C. Suryandari. 2016. "Peningkatan Keaktifan dan Hasil Belajar Matematika melalui Model Problem Based Learning Siswa Kelas V SD Negeri 5 Kutosari," Kalam Cendekia, 4(3).

9. Mubarak, Wahit lqbal, dkk. 2007. Promosi Kesehatan: Sebuah Pengantar Proses Belajar Mengajar dalam Pendidikan. Yogyakarta: Graha Ilmu.

10. Azwar, Saifuddin. 2012. Sikap Manusia. Yogyakarta: Pustaka Pelajar.

11. Arimurti, Ditta Irma. 2012. "Pengaruh Pemberian Komik Pendidikan Gizi Seimbang terhadap Pengetahuan Gizi Siswa Kelas V SDN Sukasari 4 Kota Tangerang," Skripsi. Depok: Fakultas Kesehatan Masyarakat Prodi Gizi Universitas Indonesia

12. Fitri, Cahya Ning. 2012. "Faktor-faktor yang berhubungan dengan Kebiasaan Makanan Jajanan pada Siswa Sekolah Dasar di SDN Rawamangun 01 Pagi Jakarta Timur," Skripsi. Depok: Program Studi Ilmu Gizi Universitas Indonesia.
13. Duncan, Randy \& Matthew J. Smith. 2009. The Power of Comics: History, Form, and Culture. USA: The Continuum International Publishing Group

14. Hermawati, Tetty. 2015. Komik Digital untuk Pembelajaran yang Menyenangkan. http://guraru.org. 8 Februari 2017

15. 15 Saloso, Imam. 2011. “Pengaruh Media Audio (lagu anak-anak) dan Media visual (kartu bergambar) terhadap pengetahuan gizi (PUGS dan PHBS) serta tingkat penerimaannya pada Anak usia Sekolah Dasar Negeri di Kota Bogor," Skripsi. Bogor: Fakultas Ekologi Manusia IPB.

16. 16 Kemenkes RI. 2014. Pedoman Gizi Seimbang. Jakarta: Kemenkes RI.

17. Hamida, Khairuna, Siti Zulaekah,\& Mutalazimah. 2012. "Penyuluhan Gizi dengan Media Komik untuk Meningkatkan Pengetahuan tentang Keamanan Makanan Jajanan," Jurnal Kesehatan Masyarakat, 8 (1)

18. Nurhasanah, Aan, dkk. 2014. "Pengaruh Pendidikan Kesehatan terhadap Peningkatan Pengetahuan, Sikap, dan Perilaku tentang Jajanan Sehat pada Murid Sekolah Dasar," Jurnal Keperawatan Poltekkes Kemenkes Jakarta III, 2(3).

19. Notoatmodjo, Soekidjo. 2005. Metodelogi Penelitian Kesehatan. Jakarta: PT. Rineka Cipta. 